
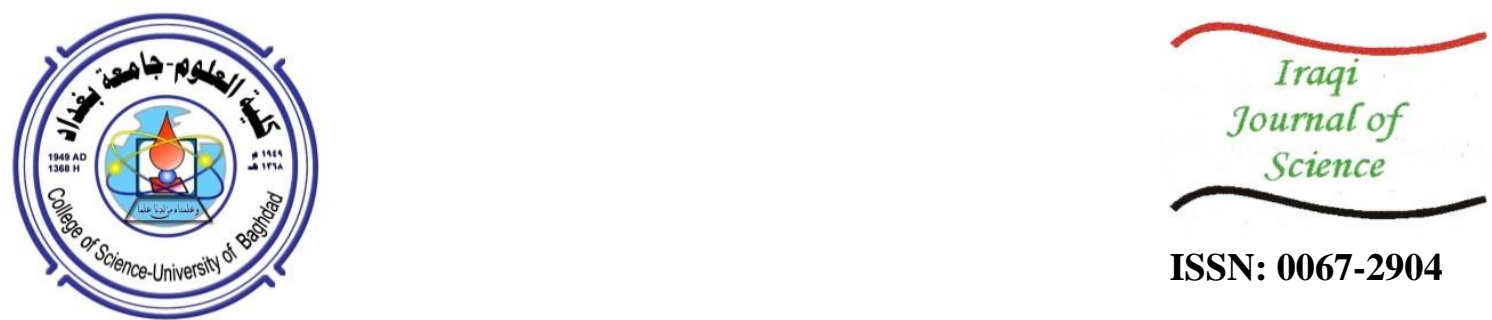

ISSN: 0067-2904

\title{
Estimation and Analysis of Solar Radiation on Horizontal and Inclined Surface for Baghdad City
}

\author{
Basheer Khaleel Ahmed, Ghada Ghanim Younis *, Zakria Abdalwahid \\ Department of New and Renewable Energies, College of Science, University of Mosul, Mosul, Iraq
}

Received: $10 / 1 / 2021$

Accepted: 26/6/2021

\begin{abstract}
The knowledge of the quantity of total solar radiation on horizontal and inclined surfaces is very important in the calculations of heating and cooling loads in architecture and in the design of certain solar energy applications such as photovoltaic and solar collectors. This paper estimates the total solar radiation on inclined surfaces in Baghdad (Lat. $33^{\circ} 21^{\prime} \mathrm{N} \quad 44^{0} 14^{\prime}$ long and $34 \mathrm{~m}$ above MSL). A good model was used to estimate hourly total solar radiation on the inclined surface with different elevations $\left(15^{0}, 30^{0}, 45^{0}, 60^{\circ}, 75^{0}, 90^{\circ}\right)$ from a horizontal surface. The mean hourly, daily and monthly variation of total solar radiation on horizontal and inclined surfaces were drawn and discussed. The optimum tilt angle over a period of a year was drawn and discussed. Linear regression equations correlating the mean hourly solar radiation on an inclined surface with mean hourly solar radiation on a horizontal surface was deduced with high correlation coefficient $(0.98-0.99)$.
\end{abstract}

Keywords: Hourly Solar Radiation, Solar Altitude, Solar Azimuth Angle, Latitude, Hour Angle.

\section{حساب وتحليل شدة الاشعاع الشمسي الساقط على السطح الافقي والاسطح المائلة لمدينة بغداد

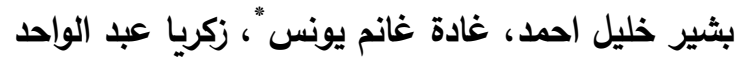

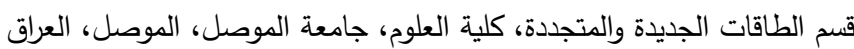

تعد معرفة كمية الاشعاع الثمسي الساقط على السطح الافقي وعلى الاسطح المائلة مهمة جدا في تحديد

مواقع مشاريع المنظومات التي تعمل بالطاقة الثمسية وكذلك تعد الاساس في تصميم وتقييم اداء تلك

المنظومات. ان جميع المنظومات الحرارية المتمثلة بالمجمعات الثمسية المركزة والمسطحة المستخدمة في

التدفئة والتبريد وتزويد الماء الساخن وكذلك منظومات الخلايا الثمسية تتطلب معرفة كمية الاشعاع الثمسي

الساقط على الاسطح المائلة بزوايا ميل مختلفة عن السطح الافقي. لذا في هذا البحث تم حساب وتحليل القيم

الساعية واليومية والثهرية للإثعاع الشمسي الساقط على الاسطح الافقية والمائلة بزوايا ميل مختلفة ابتدأ من

$15^{0}$

وعلى ارتفاع 34 متر فوق مستوى سطح البحر. تم رسم وتحليل التغيرات الساعية الثهرية واليومية الثهرية

"Email: ghadaghanim@uomosul.edu.iq 


$$
\begin{aligned}
& \text { لكمية الاشعاع الثمسي الساقط على الاسطح ولجميع الزوايا قيد الدراسة، ولوحظ ان اقل قيم سجلت عند }
\end{aligned}
$$

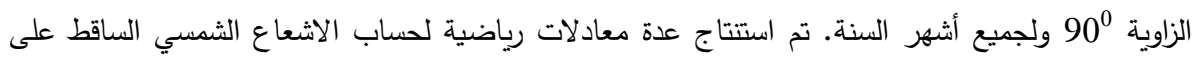

$$
\begin{aligned}
& \text { الاسطح المائلة وبزوايا مختلفة اعتمادا على كمية الاشعاع الثمسي الساقط على السطح الافقتي، وكانت } \\
& \text { معاملات الارتباط عالية تتراوح بين (0.99 -0.98) }
\end{aligned}
$$

\section{Introduction}

Quantitative data of solar radiation falling on a horizontal surface and inclined surface are essential input parameters for the design of solar energy conversion systems, the selection of optimum sites for solar power stations, for building load analysis and for computing the efficiency of various systems[1].

The amount of total solar radiation on a horizontal surface and on an inclined surface depends on several parameters such as the geometry of the site (latitude and longitude), time of the day, zenith distance of the sun and atmospheric parameters, and slope of the collector surface or photovoltaic panels[2].

A study of the total, diffuse, direct solar radiation on the horizontal and inclined surfaces have been carried out by Chandel and Aggarwal [3]. Daily and monthly values of solar radiation on a sloping surface was studied and approximated by McAneney and Noble [4].

Muzathik et al. (Malaysia) [5] estimated the hourly and daily global solar radiation on a horizontal plane using empirical models and the results were compared with measured data.

K. J. McAneney and P. F. Noble (Muscat / Oman) [6] studied the effect of tilt angle and orientation of inclined surface on solar radiation flux. Baklouit et al. (Sfax/ Tunisia) [7] used a different model to estimate the intensity of solar radiation on a horizontal and inclined surface. Kumar et al.(India) [8] described a detailed evaluation of solar location on monthly basis.

The purpose of this paper is to estimate and analyze the intensity of total solar radiation on an inclined surface with slope angles of $\left(15^{\circ}, 30^{\circ}, 45^{\circ}, 60^{\circ}, 75^{\circ}\right.$ and $\left.90^{\circ}\right)$ from a horizontal surface. The mean hourly, daily and monthly total solar radiation on the inclined surface were captured and their monthly variations are discussed and analyzed.

\section{Position of the Sun Relative to Inclined Surfaces}

The position of the sun with respect to an inclined surface is necessary to prescribe the slope of the surface to the horizontal or vertical position and its orientation. Figure 1 describes such surface[9].

$\beta$ - slope of the surface from horizontal position, in degrees.

$\theta$ - the angle between normal to the surface and sun-earth vector, in degrees.

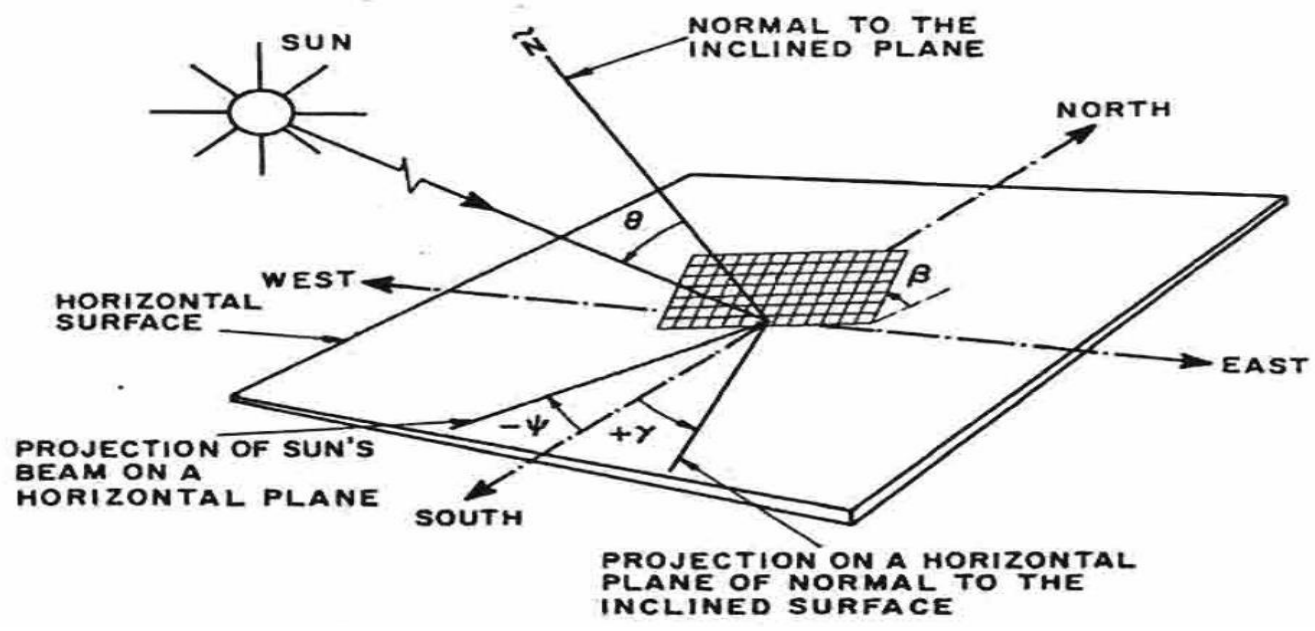

Figure 1-Position of sun relative to an inclined plane [9]. 


\section{Theoretical Part}

Because there is no measuring instrument to measure the intensity of total solar radiation on horizontal and inclined surfaces they are estimated from an empirical model.

The model used to estimate total solar radiation on inclined surface depends on several parameters such solar altitude angle, solar azimuth angle and the slope of inclined surfaces from horizontal surfaces as in the given equation [10]:

$$
R_{s}=R_{h}(\sin h \sin \beta+\cos h \sin e \beta \cos A)
$$

where $R_{s}$ is the hourly total solar radiation on inclined surface, in $W / m^{2} ; R_{h}$ is the hourly total solar radiation on horizontal surface, in $\mathrm{W} / \mathrm{m}^{2} ; \mathrm{h}$ is the solar altitude angle, in degree, which is calculated from the equation:

$$
h=\sin ^{-1}(\sin \varphi \sin \delta+\cos \varphi \cos \delta \cos \omega)
$$

where $\varphi$ is latitude of the location which is equal to $33^{0} 21^{\prime}$ for Baghdad city; $\delta$ is declination angle, in degree; which is calculated from the equation:

$$
\delta=23.45 \sin \left[\frac{360}{365}\left(284+d_{n}\right)\right]
$$

where $\mathrm{d}_{\mathrm{n}}=$ the day number of the year ranging from 1 on $1^{\text {st }}$ January to 365 on 31 December; $\omega=$ the hour angle, in degree; which calculated from the equation:

$$
\omega=\frac{360}{24}(12-t)
$$

where $\mathrm{t}=$ the hours of day, in hour; $\mathrm{A}=$ the solar azimuth angle, in degree; which calculated from the equation:

\section{Analysis and Results}

$$
A=\sin ^{-1}(\sin \omega \cos \delta \sin h)
$$

The hourly, daily values of intensity solar radiation falling on horizontal and inclined surfaces with different elevations are analyzed as follow:

\subsection{Hourly Variation}

The monthly average of hourly intensity of solar radiation falling on horizontal and inclined surfaces with different elevations for each month are shown in Figure 2 and the statistical distribution of hourly intensity of solar radiation falling on an inclined surface are shown in the Figure 3.

The diurnal variation of the intensity of solar radiation falling on inclined surfaces exhibits similar pattern for all elevations. For all months, the peak values for all months of a year occur generally at solar noontime and the maximum values are listed in Table 1. This is because the solar radiation has travelled less distance through the atmosphere with little tendency for scattering, absorption and reflection during solar noontime, but minimum values occurred in early morning and late afternoon. 

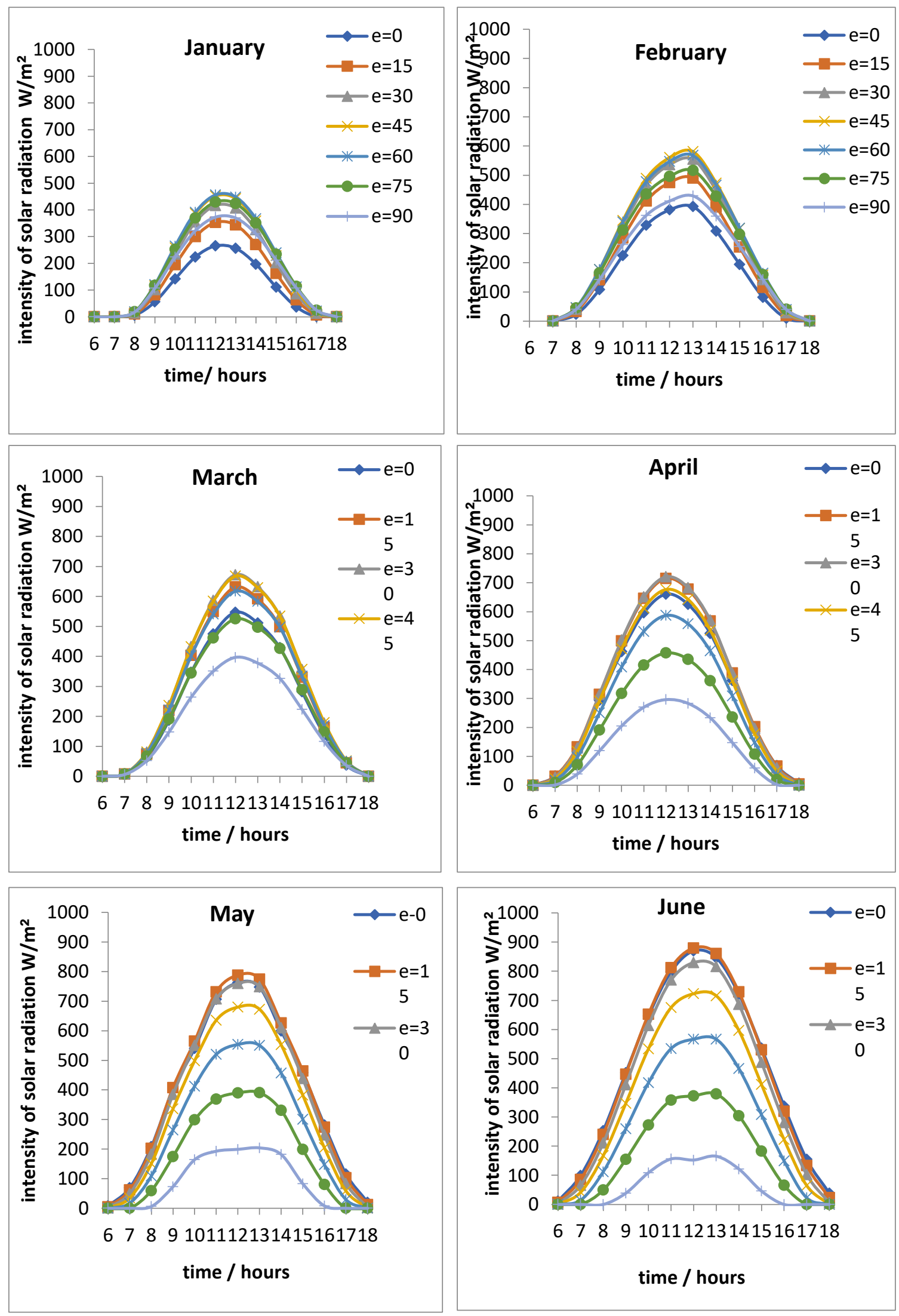

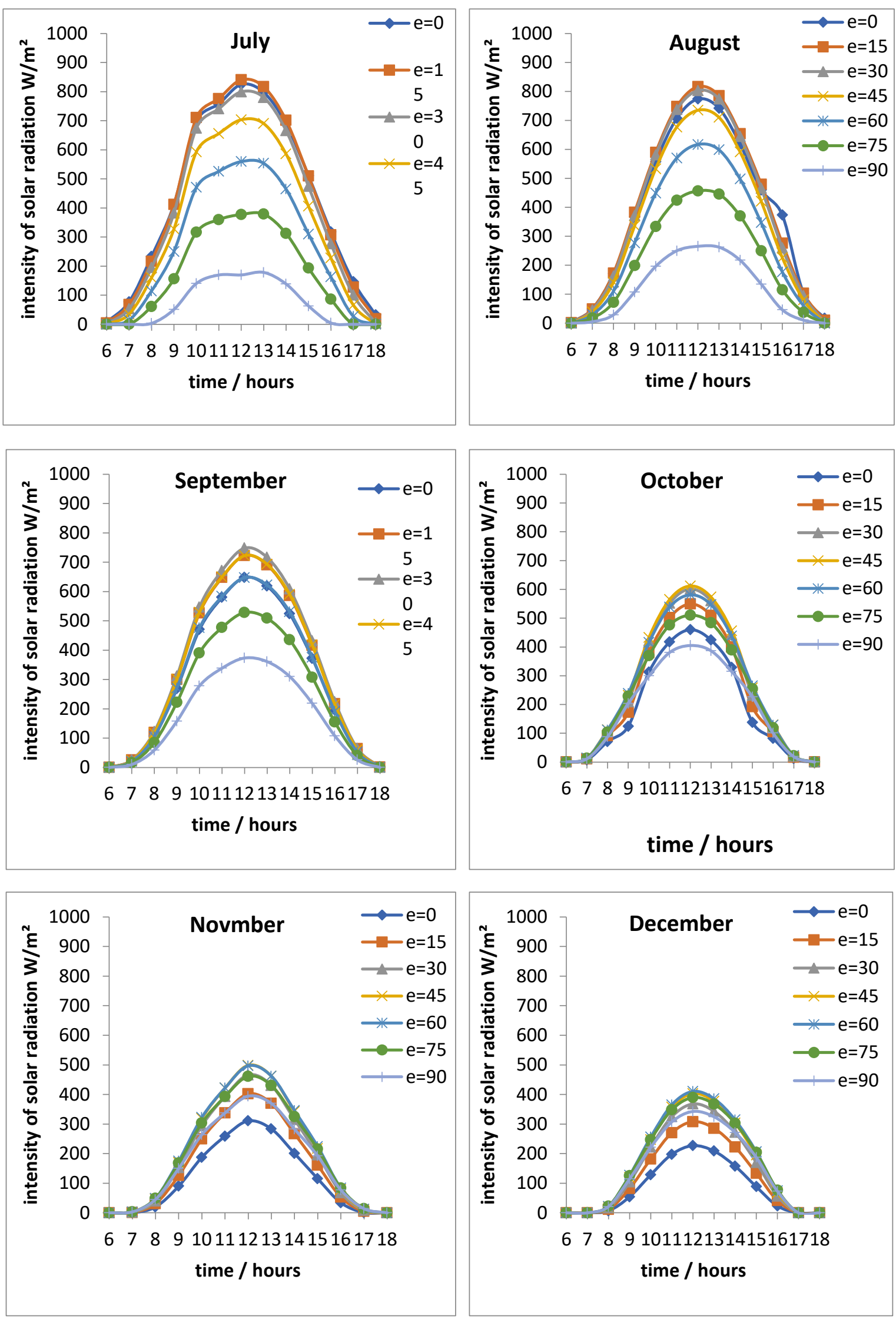

Figure 2- The monthly variation of hourly solar radiation falling on inclined surfaces 

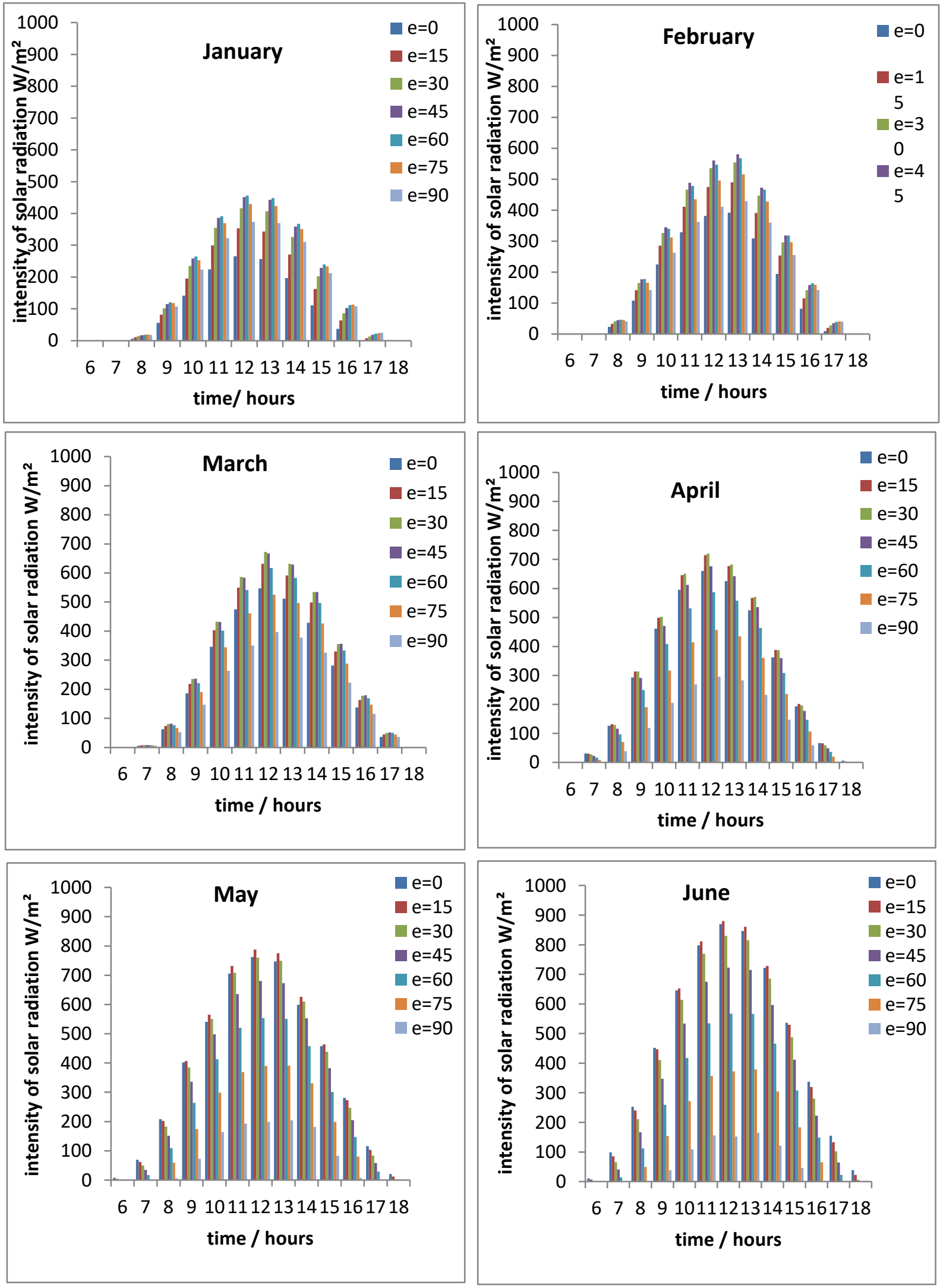

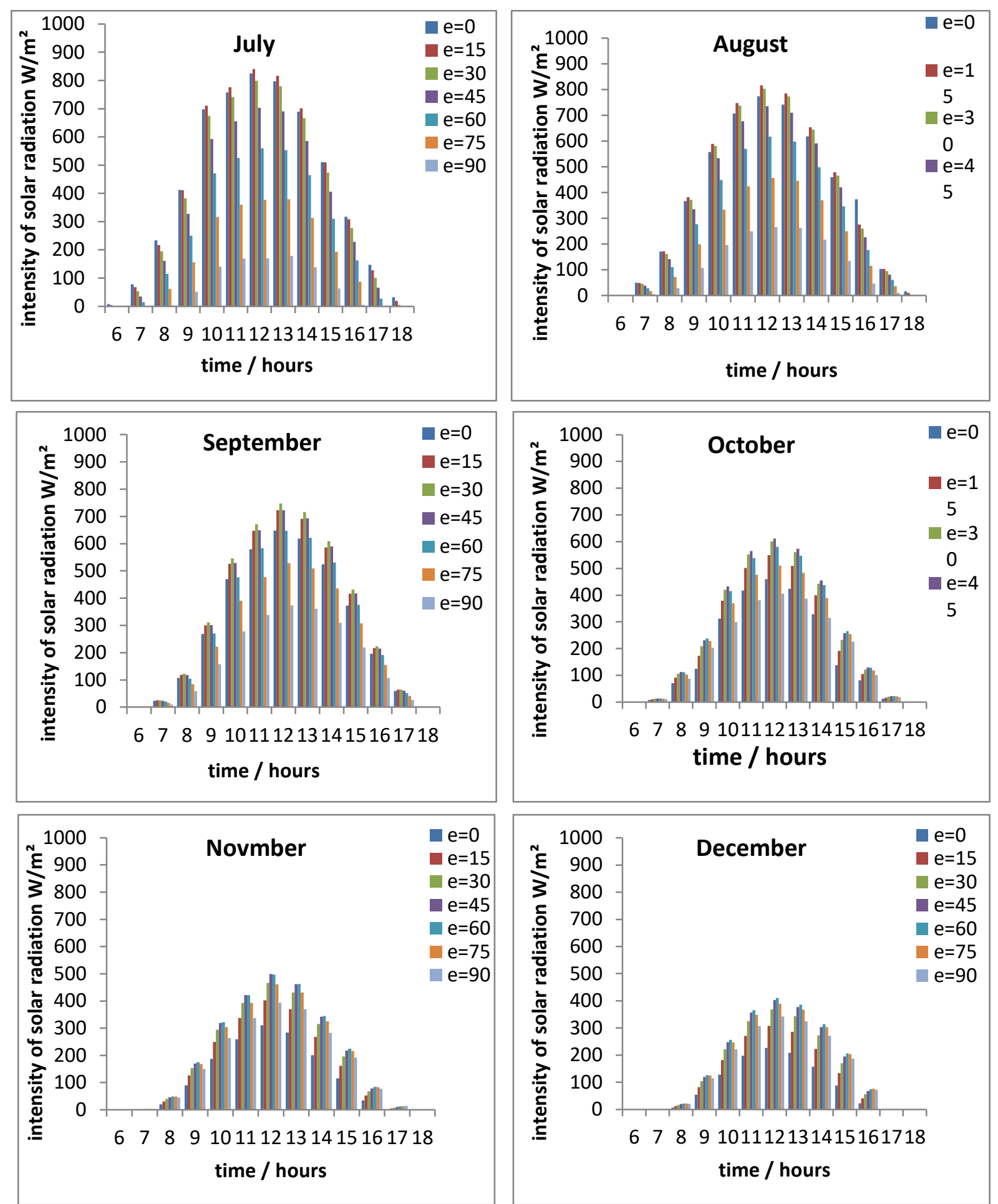

Figure 3-Statistical distribution of hourly intensity of solar radiation falling on an inclined surface.

From Table 1 the results show that the highest values of solar radiation over a period year are recorded at elevation angle 300 which equal to $(7720 \mathrm{~W} / \mathrm{m} 2)$. This evaluation equal to the latitude of Baghdad city which is called optimum tilt angle in which the solar system collects more solar energy with high efficiency. 
Table 1- The month of Solar Radiation on different inclined surface W/m ${ }^{2}$

\begin{tabular}{|c|c|c|c|c|c|c|c|}
\hline Month & $\mathbf{0}^{\mathbf{0}}$ & $\mathbf{1 5}^{\mathbf{0}}$ & $\mathbf{3 0}^{\mathbf{0}}$ & $\mathbf{4 5}^{\mathbf{0}}$ & $\mathbf{6 0}^{\mathbf{0}}$ & $\mathbf{7 5}^{\mathbf{0}}$ & $\mathbf{9 0}^{\mathbf{0}}$ \\
\hline Jan. & 266 & 353 & 417 & 452 & 456 & 429 & 373 \\
\hline Feb. & 381 & 475 & 536 & 560 & 547 & 496 & 411 \\
\hline Mar. & 547 & 631 & 672 & 668 & 617 & 525 & 397 \\
\hline Apr. & 661 & 715 & 720 & 677 & 587 & 457 & 296 \\
\hline May & 762 & 788 & 760 & 680 & 553 & 389 & 199 \\
\hline Jun. & 870 & 880 & 830 & 723 & 567 & 372 & 152 \\
\hline Jul. & 825 & 841 & 799 & 703 & 560 & 377 & 169 \\
\hline Aug. & 774 & 816 & 803 & 735 & 617 & 457 & 265 \\
\hline Sep. & 648 & 723 & 748 & 722 & 648 & 528 & 373 \\
\hline Oct. & 460 & 550 & 601 & 612 & 581 & 510 & 404 \\
\hline Nov. & 311 & 402 & 466 & 499 & 497 & 461 & 394 \\
\hline Dec. & 227 & 308 & 368 & 403 & 410 & 390 & 342 \\
\hline Total & 6642 & 7482 & 7720 & 7434 & 6640 & 5391 & 3775 \\
\hline Average & 554 & 624 & 643 & 620 & 553 & 449 & 315 \\
\hline
\end{tabular}

\subsection{Daily variation}

The mean daily values of solar radiation intensity with different inclined surfaces are shown in Figure 4. I It can be seen that the variation of solar radiation on the inclined surfaces of angles $(45,30,15,0)$ degree have similar pattern. It starts with small values from January and increases gradually to June when it records maximum values and then decreases to minimum values in December.

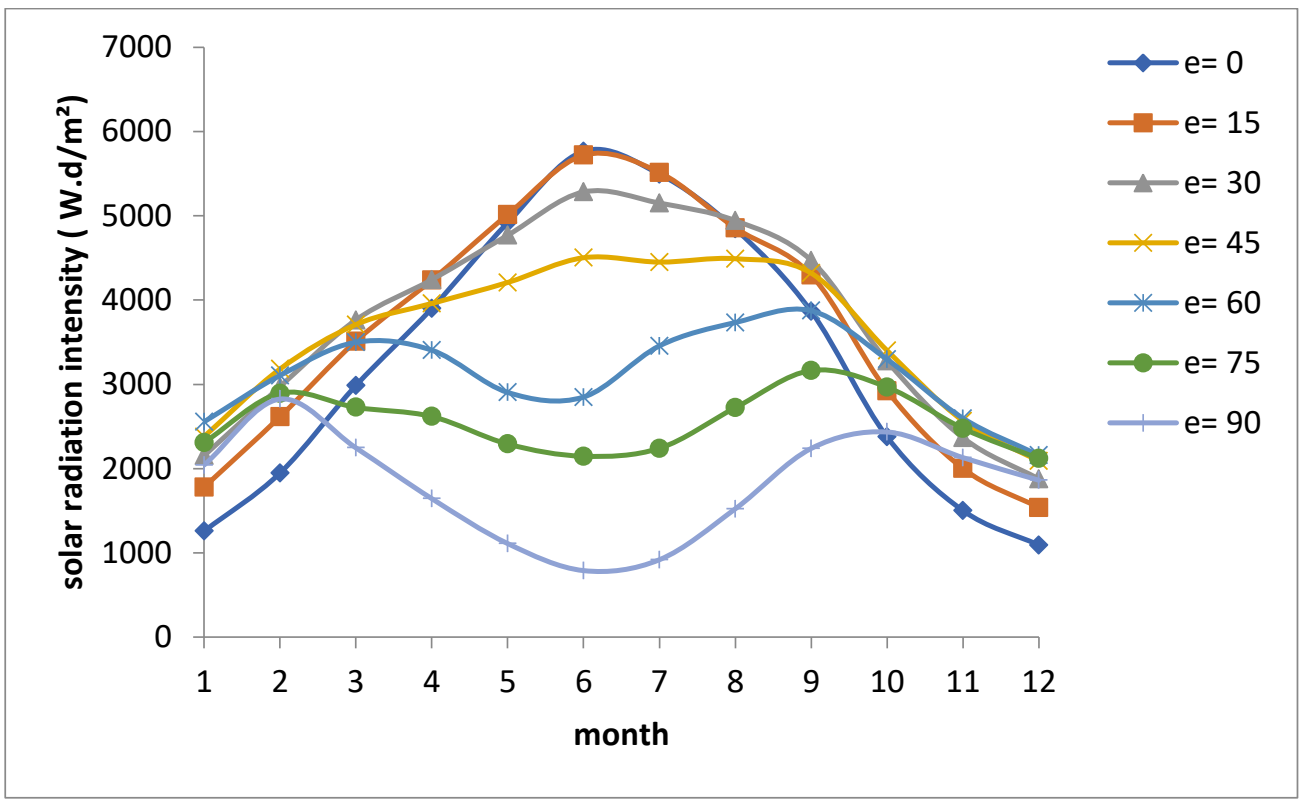

Figure 4- Monthly variation of mean daily solar intensity radiation on inclined surfaces.

But on inclined surfaces $(60,75,90)$ degree, it starts with large values in January and then decreases to minimum values in June and then increases in December. Table 2 shows the maximum and minimum values for all inclined surfaces with their months. These results are in agreement with a previous study conducted in Mosul city [11]. 
Table 2- The maximum and minimum values for all inclined surfaces with its months.

\begin{tabular}{|c|c|c|c|c|}
\hline $\begin{array}{l}\text { Tilt angle } \\
\text { (degree) }\end{array}$ & $\begin{array}{c}\text { max. values } \\
\left(W / \mathbf{m}^{2}\right)\end{array}$ & month & $\begin{array}{c}\text { min. values } \\
\left(\mathrm{W} / \mathbf{m}^{2}\right)\end{array}$ & month \\
\hline 0 & 5764 & Jun & 1093 & Dec. \\
\hline 15 & 5718 & Jun & 1538 & Dec. \\
\hline 30 & 5282 & Jun & 1877 & Dec. \\
\hline 45 & 4502 & Jun & 2088 & Dec. \\
\hline 60 & 3873 & Sep. & 2159 & Dec. \\
\hline 75 & 3164 & Sep. & 2118 & Dec. \\
\hline 90 & 2825 & Feb. & 1862 & Dec. \\
\hline
\end{tabular}

\subsection{The Optimum Tilt Angle}

Figure 5 explains the monthly variation of optimum tilt angle which starts with high values in January at $60^{\circ}$ tilt angle and reduces to minimum values at summer months at a tilt angle of $15^{\circ}$ and then increases in December at $60^{\circ}$ tilt angle. This variation is a result of the monthly variation of solar altitude angle. The average optimum tilt angle over a period of a year was found to be $33^{0} 37^{\prime}$ which is equal to the latitude of Baghdad city (Baghdad latitude $33^{0} 21^{\prime}$ ). In the summer months the optimum tilt angle was reduced to $15^{\circ}$, but in the winter months it increased to $51^{0}$.

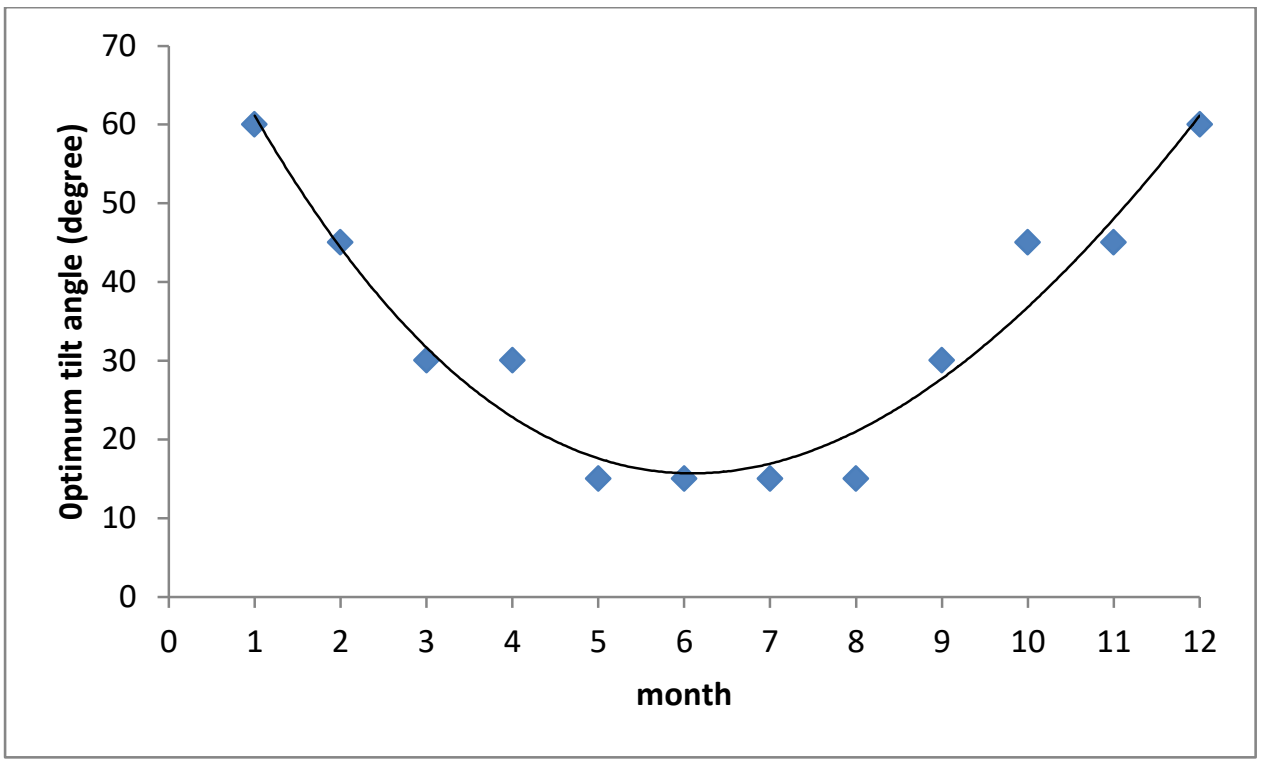

Figure 5-The monthly variation of optimum tilt angle.

\subsection{The Correlation Between Solar Intensity on Inclined Surfaces with that on the Horizontal Surface:}

The mean hourly of solar radiation falling on inclined surfaces and mean hourly of solar radiation falling on horizontal surfaces for the recorded period are correlated.

The curve fitting method was applied as shown in Figure 6 and four second-order polynomial regression equations of the form $\left(y=A x^{\wedge} 2+B x+c\right)$ were deduced. 

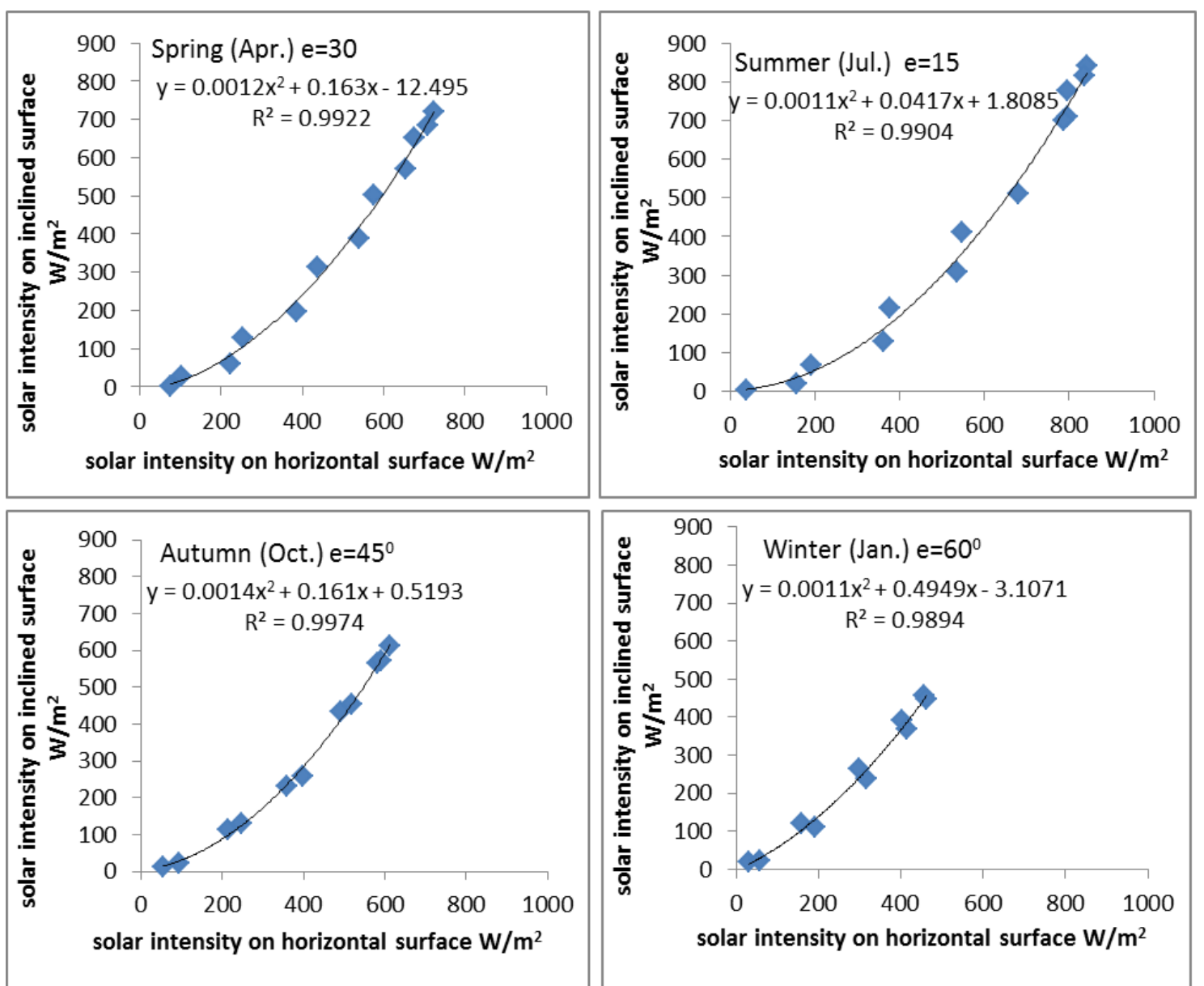

Figure 6-The second order equation correlation between mean hourly solar radiation falling on inclined surfaces with falling on horizontal surface.

The values of A, B and C for the deduced equations and its Root Mean Square Error (RMSE), Mean Bias Error (MBE), Standard Deviation (S.D) and correlation coefficient (C.C) are shown in Table 3 . These equations are useful to estimate the values of solar radiation intensity on inclined surfaces when there is no instrument.

Table 3- The fitted second order equations of (SRIS) as a function of ( $\mathrm{SRhS})$ and it is (RMSE), (MBE), (S.D) and (C.C).

\begin{tabular}{c|ccccccc}
\hline Tilt angle & A & B & C & C.C & MBE & RMSE & S.D \\
\hline $15^{0}$ & .0011 & .0417 & 1.8085 & 0.9904 & -0.242 & 0.4919 & 0.428 \\
$30^{0}$ & .0012 & .163 & -12.495 & 0.9922 & -0.279 & 0.528 & 0.448 \\
$45^{0}$ & .0014 & .161 & .5193 & 0.9974 & -0.319 & 0.565 & 0.466 \\
$60^{0}$ & .0011 & .4949 & -3.1071 & 0.9894 & -0.225 & 0.4743 & 0.418 \\
\hline
\end{tabular}

\section{Conclusions}

The following points were concluded from this work:

1- The maximum values of intensity of solar radiation falling on inclined surfaces occurs at solar noontime as a result of high solar altitude angles and low optical air mass.

2- The highest values of solar radiation intensity on all inclined surfaces were recorded in June and the lowest values were recorded in December.

3- The average optimum tilt angle over a period of the year was equal to $33^{0} 37^{\prime}$ which is equal to the latitude of location of Baghdad city.

4- In summer months, the optimum tilt angle was equal to $\varphi-20$ degree where $\varphi$ is the latitude of Baghdad city.

5- In winter months, the optimum tilt angle was equal to $\varphi+20$ degree. 
6- The mean daily values of solar radiation falling on different inclined surfaces are drawn and discussed, and the maximum and minimum values for all inclined surfaces were explained in the Table 2.

7- Four second-order equations are deduced between mean hourly solar radiation falling on inclined surfaces and mean hourly on a horizontal surface with high correlation coefficient of (0.98-0.99).

8- The minimum values of solar radiation intensity on a period of year are recorded at 90 degree elevation from a horizontal surface for all months.

\section{Nomenclature}

$\beta$ - slope of the surface from horizontal position, degree.

$\theta$ - the angle between normal to the surface and sun-earth vector, degree.

$\mathrm{R}_{\mathrm{s}}$ - the hourly total solar radiation on inclined surface, $\mathrm{W} / \mathrm{m}^{2}$.

$\mathrm{R}_{\mathrm{h}}$ - the hourly total solar radiation on horizontal surface, $\mathrm{W} / \mathrm{m}^{2}$.

$\mathrm{h}$ - solar altitude angle, degree.

$\varphi$ - latitude of location (Baghdad city $33^{0} 21^{\prime}$ ).

$\delta$ - Declination angle, degree.

$\mathrm{d}_{\mathrm{n}}$ - the number of days in the year.

$\omega$ - the hour angle, degree.

$\mathrm{t}$ - the hours of days, hour.

A- the solar azimuth angle, degree.

\section{Acknowledgment}

We would like to show our gratitude to the University of Mosul/ College of science, for their provided facilities, which helped to improve the quality of this study.

\section{Reference}

[1] K.-D. Jäger, O. Isabella, A. H. M. Smets, R. A. van Swaaij, and M. Zeman, Solar energy: fundamentals, technology and systems. UIT Cambridge, 2016.

[2] S. A. Mousavi Maleki, H. Hizam, and C. Gomes, "Estimation of hourly, daily and monthly global solar radiation on inclined surfaces: Models re-visited," Energies, vol. 10, no. 1, pp. 134, 2017.

[3] C. Shyam S and A. Rajeev K, "Estimation of hourly solar radiation on horizontal and inclined surfaces in Western Himalayas," Smart grid Renew. energy, vol. 2011, 2011.

[4] K. J. McAneney and P. F. Noble, "Estimating solar radiation on sloping surfaces," New Zeal. J. Exp. Agric., vol. 4, no. 2, pp. 195-202, 1976.

[5] A. M. Muzathik, W. M. N. W. Nik, K. Samo, M. Z. Ibrahim, and others, "Hourly global solar radiation estimates on a horizontal plane," J. Phys. Sci., vol. 21, no. 2, pp. 51-66, 2010.

[6] N. Z. Al-Rawahi, Y. H. Zurigat, and N. A. Al-Azri, "Prediction of hourly solar radiation on horizontal and inclined surfaces for Muscat/Oman," J. Eng. Res. [TJER], vol. 8, no. 2, pp. 19-31, 2011.

[7] I. Baklouti, Z. Driss, and M. S. Abid, "Estimation of solar radiation on horizontal and inclined surfaces in Sfax, TUNISIA," in 2012 First International Conference on Renewable Energies and Vehicular Technology, 2012, pp. 131-140.

[8] M. R. Kumar, B. B. S. Babu, and M. Seshu, "Estimation of Average Solar Radiation on Horizontal and Tilted Surfaces for Vijayawada Location," J. Electr. Electron. Eng., vol. 11, pp. 43-53, 2016.

[9] M. Iqbal, An introduction to solar radiation. Elsevier, 2012.

[10] M. AlRiahi, "Availability of Solar Radiation on Oriented Surface in Iraq During Cloudless days," Al- Mustanseria University, Baghdad - Iraq, 1979.

[11] B. K. Ahmed, "calculation analyze solar energy falling on inclined south facing surface in mosul city and determine optimum tilt angle.," Rafidain J. Sci., vol. 13, no. 3, pp. 90-100, 2002. 